\title{
KAMPUNG NAGA: \\ Sebuah Representasi Arsitektur sebagai Bagian dari Budaya
}

\author{
LufukMaslucha \\ Jurusan Arsitektur Fakultas Sains dan Teknologi UIN Maulana Malik Ibrahim Malang. Jalan Gajayana 50 \\ Malang 65114. Telp. 0341-551354.
}

\section{Abstract}

In this article, the uriter tries to study architecture as a cultural product of a certain society because architecture is a representation of social life in eneral and individual. Therefore, studying architecture cannot be separated from the three basic elements, that is, concept, method, and performance. All of them are unified in value, need, and physical performance. Architecture is a part of culture composed from each element of culture itself and includes in the cultural system. The cultural elements included in architecture are concept, thought and rules, attitude and behavior as a social system. Both cultural system and social system build architecture as artefactual physical performance. The simplicity of Kampung Naga architecture shows the great value of the societys culture that is represented in its elements. Kampung Naga architecture also shows beauty coming from simplicity and humbleness. Beauty can appear from something parametrical or measurable and those non parametrical and immeasurable. Measurable things may be able to be seen physically, but the unmeasureable can only be felt. Architecture influenced by culture with its whole elements can raise behaviour patterns. Therefore, architecture should be built with the base and spirit of great culture to build great behaviour.

Key words: architecture, culture, Kampung Naga 


\section{Pendahuluan}

Arsitektur merupakan satu bidang kajian yang sangat luas dan didalamnya terdapat berbagai macam sudut pandang keilmuan yang menaunginya. Berbicara tentang arsitektur, maka tidak akan lepas dari budaya. Arsitektur merupakan hasil dari budaya sebuah masyarakat, karena karya arsitektur merupakan satu pengejawantahan dari kehidupan suatu masyarakat secara umum, dan pengejawantahan diri pribadi seseorang. Dalam telaah arsitektur mempunyai tiga unsur pokok, yaitu konsep, cara membangun dan tampilan karya, ketiganya menyatu dalam makna, tuntutan kebutuhan dan penampilan/kenyataan tempat tinggal secara fisik (Ronald, 2007: 89).

Bentuk estetika dapat dianalogikan dengan gagasan, buah pikir atau wacana (idealisme), yang merupakan wujud dari kebudayaan yang pertama yang letaknya paling dalam, abstrak, dan plastis dan bentuk tersebut tidak dapat dirumuskan secara pasti. Sedangkan cara membangun dapat dikaitkan dengan perbuatan yang merupakan wujud kebudayaan yang kedua, yang dapat dibaca melalui sikap dan perilaku orang dalam rangka merealisasikan gagasan untuk menjadi kenyataan. Tampilan karya secara langsung dapat diartikan dengan artefak yang merupakan wujud budaya yang ketiga (Sunaryo, 2007: 65).

Dari pendapat di atas dapat ditelaah kembali bahwa arsitektur sebagai sebuah karya merupakan olahan fungsi yang ditransformasikan ke dalam bentuk dan ruang yang terangkum menjadi satu. Namun karya arsitektur bukanlah sekedar masalah ruang dan bentuk, lebih dari itu, arsitektur mampu merangkum seni dalam satu bagian yang utuh, untuk menghadirkan sebuah keindahan. Oleh karena itu keindahan yang dihasilkan tidak hanya keindahan fisik belaka, tetapi yang lebih penting adalah keindahan makna. Fungsi-fungsi yang diolah oleh arsitek, merupakan pengertian secara sederhana dari kegunaan. Fungsi juga dapat dimaknai sebagai suatu cara untuk memenuhi keinginan yang timbul akibat adanya kebutuhan manusia dalam mempertahankan dan mengembangkan hidupnya. Dari penjelasan ini dapat dilihat bahwa manusia mempunyai posisi yang penting dalam perannya sebagai khalifah untuk mengelola alam dalam bingkai lingkungan binaan. 
Dari pengertian arsitektur di atas dan bagaimana kedekatan arsitektur dengan ilmu bahasa berkaitan dengan bagaimana pendekatan keilmuannya, maka dapat dijelaskan bahwa arsitektur merupakan satu bidang yang tidak hanya berbicara dan berhubungan dengan yang bersifat fisik saja, tetapi arsitektur juga merupakan satu ilmu yang juga berhubungan dengan yang non fisik, yang terukur dan tidak terukur. Berarti, arsitektur yang sesungguhnya harus meliputi guna dan citra, yaitu mampu memberi makna dari materinya, berangkat dari eksistensi manusia: jasmani dan rohani yang bila dipisahkan akan mati serta membahasakan dan mencerminkan jati diri (Mangunwijaya, 1995: 53).

Dari konsep guna dan citra tersebut dapat dijelaskan bahwa arsitektur harus dapat memberi makna pada bangunan fisiknya. Sebuah karya arsitektur sebagai bagian dari hasil kebudayaan, tentunya tidak lepas dari aktivitas atau perilaku manusia didalamnya dan ketika dia didirikan. Oleh karena itu, makna yang terkandung dalam sebuah karya arsitektur juga tidak lepas dari perilaku manusia yang mendiaminya dan kebudayaan yang mempengaruhinya, dan makna pada arsitektur merupakan bagian non fisik yang mempunyai posisi penting dalam pembentukan sebuah arsitektur yang berguna dan citra. Selain itu, arsitektur merupakan satu bidang yang didalamnya terangkum rangkaian keterkaitan dengan unsur-unsur kebudayaan manusia.

\section{Kajian tentang Budaya}

Budaya berasal dari kata buddhayah (jamak), buddhi (tunggal), dan budi yang berarti akal atau hal-hal yang bersangkutan dengan akal. Sedangkan akal sendiri merupakan kemampuan untuk memodifikasi pikiran, sehingga kebudayaan dapat diartikan sebagai sesuatu yang berkaitan dengan akal. Budaya dan kebudayaan bila didefinisikan dari sudut pandang antropologi merupakan keseluruhan sistem gagasan, tindakan, dan hasil karya manusia dalam rangka kehidupan masyarakat yang dijadikan milik diri manusia dengan cara belajar (Ronald, 2007: 71). Hal ini mencakup seluruh kehidupan manusia sejak lahir sampai dengan mati.

Sedangkan wujud dari budaya adalah ide atau gagasan, tindakan atau 
aktivitas, dan hasil karya atau artefak. Unsur-unsur kebudayaan adalah bahasa, sistem, pengetahuan, organisasi atau sistem sosial, sistem peralatan hidup dan teknologi, sistem mata pencaharian hidup (sistem ekonomi), sistem religi dan kesenian (Koentjaraningrat, 2005: 26).

Dari ketujuh unsur tersebut terdapat tiga bagian pengelompokan, yaitu:

a. Sistem kebudayaan: konsep, pemikiran, aturan

b. Sistem sosial: sikap, perilaku, tindakan

c. Lingkungan fisik: artefaktual

Secara kasat mata arsitektur berada pada ranah lingkungan fisik atau artefaktual. Tetapi apabila dikaji lebih dalam lagi, arsitektur dapat meliputi semua aspek yang ada dalam pengelompokkan tujuh unsur budaya tersebut. Hal ini dikarenakan bahwa dalam arsitektur dapat memuat sistem kebudayaan yang berupa konsep, pemikiran, dan aturan, dapat juga memuat dan membentuk sikap, perilaku dan tindakan. Untuk lebih jelasnya akan dijelaskan pada pokok bahasan selanjutnya.

\section{Hubungan Arsitektur dan Budaya}

Arsitektur adalah ekspresi tiga dimensi dari perilaku manusia, perilaku dalam hal ini dapat disejajarkan dengan perbuatan berarti sebagian dari kebudayaan. Dari uraian ini telah lebih jelas lagi bahwa arsitektur juga mempunyai hubungan dengan kebudayaan (Ronald, 2007: 33). Pola perilaku dari manusia pada dasarnya dipertimbangkan oleh satu hubungan yang kuat antara satu aktivitas dari manusia dan sebuah tempat yang ciri-cirinya terdiri dari (Ronald, 2007: 99):

a. Sebuah pola aktivitas yang berulang sebuah kedudukan pola perilaku

b. Suatu lay out tertentu dari satu lingkungan-lingkungan pergaulan

c. Sebuah hubungan yang selaras seimbang antar dua keterkaitan

d. Sebuah periode waktu yang spesifik.

Dari kutipan di atas dapat dijelaskan bahwa karya arsitektur dapat didasari oleh pola perilaku dari suatu komunitas masyarakat, sehingga didapatkan karya dengan rancangan yang sesuai dengan pola perilaku dan 
kebiasaan mereka. Arsitektur dirancang dan didirikan dengan mempelajari pola perilaku manusia dan masyarakat yang akan tinggal didalamnya, selain itu arsitektur itu sendiri juga dapat membentuk pola perilaku dari rancangan yang telah berdiri. Dari mempelajari sebuah pola perilaku tersebut dapat disimpulkan bahwa arsitektur tidak dapat lepas dari perilaku manusia, karena fungsi arsitektur itu sendiri yang berfungsi sebagai wadah beraktivitas manusia. Aktivitas yang berulang merupakan pola dari perilaku. Rancangan arsitektur yang baik adalah yang dapat membaca dan mewadahi aktivitas serta pola perilaku yang ada pada manusia didalamnya (Ronald, 2007: 101).

Merupakan satu hal yang sangat naif jika seorang arsitek merancang sebuah bangunan pada sekelompok masyarakat atau manusia tetapi tidak mempelajari pola perilaku yang merupakan bagian dari kebudayaan mereka. Sangat memungkinkan jika hasil karya arsitektur tersebut akan ditinggalkan oleh penghuninya karena penghuninya yang tidak merasa nyaman dan sesuai dengan kehidupan mereka. Pernyataan ini bukan semata-mata hanya pendapat belaka, tetapi hal ini telah banyak terjadi di kehidupan kita, seperti pada perancangan apartemen Pruit Igoe dan kota Chandigardh di India yang justru hasil rancangan tersebut tidak memberikan manfaat bagi masyarakat yang menggunakannya. Banyak arsitek yang hanya mengutamakan ide pribadinya tanpa atau dengan mengabaikan pola perilaku atau aktivitas yang menjadi kebiasaan dari masyarakat didalamnya. Arsitek-arsitek yang hanya mengutamakan keinginan pribadinya tanpa mempelajari apa potensi dari satu masyarakat tersebut, baik itu potensi alam, lingkungan serta budaya didalamnya.

Dari contoh tersebut dapat dilihat bahwa arsitektur dan budaya tidak dapat dipisahkan. Contoh karya arsitektur seperti Pruit Igoe dan perancangan kota Chandigardh yang tidak mempelajari pola perilaku yang menjadi kebiasaan dan kebudayaan masyarakat setempat akan memberikan rasa tidak nyaman bagi manusia didalamnya. Selain itu, dengan didirikannya dua karya arsitektur tersebut justru menciptakan pola perilaku dan kebiasaan baru yang dibentuk dan terpola oleh karya arsitektur tersebut yang membuat penghuninya merasa tidak nyaman dengan keberadaan hasil 
arsitektur tersebut.

Dari contoh di atas, kita juga dapat melihat bahwa arsitektur berkaitan dengan kehidupan sosial di masyarakat, di mana kehidupan sosial, salah satu unsur dari kebudayaan, yang terjadi pada suatu bangunan sebagai hasil dari arsitektur sangat dipengaruhi oleh desain karya arsitektur itu sendiri. Kejahatan sebagai masalah sosial yang timbul pada apartemen Pruit Igoe tersebut dipengaruhi oleh desain sirkulasi yang tertutup. Ini hanya salah satu contoh, dan terdapat banyak sekali contoh karya arsitektur yang berkaitan erat dengan unsur-unsur budaya yang lain.

Pakar arsitektur James C. Synder dan Anthony J. Catanese menjabarkan arsitektur sebagai hasil pemikiran dalam menata ruang, waktu, kegiatan, status serta peran dan perilaku, untuk memberikan suatu penampilan fisik, pada gagasan dan mengkiaskan gagasan sebagai bantuan ingatan yang bermanfaat, sehingga gagasan ini dapat membantu perilaku manusia tentang bagaimana berperilaku dan apa saja yang diharapkan dari mereka.

Sementara itu, menurut Geoffrey Broadbent dalam bukunya Design in Architecture yang beberapa di antaranya berkaitan dengan perilaku, adalah bahwa arsitektur haruslah memiliki kaidah-kaidah Container Function, yaitu arsitektur merupakan wadah atau bungkus dari kegiatan tertentu, dan dapat menginformasikan kegiatan yang ada didalamnya kepada pengamat, sekaligus sebagai Behavior Modifier, yaitu arsitektur digunakan untuk mengatur tingkah laku manusia atau menanggapi perilaku manusia.

Dari dua pernyataan tersebut, jelas bahwa makna sebagai faktor non fisik yang terkandung dalam karya arsitektur sebagai bagian dari guna dan citra tadi, tidak lepas dari perilaku dan aktivitas manusia didalamnya. Bagaimana perilaku dan aktivitas sebagai bagian dari budaya memberikan peran yang penting dalam sebuah karya arsitektur tersebut. Sekarang, tinggal bagaimana sikap dari arsiteknya, atau yang mendirikannya, akankah dia menginginkan makna yang dalam sebagai tempat dia berhuni ataukah hanya dianggap sebagai bangunan fisik belaka.

Pengertian-pengertian di atas, menjadikan perilaku sebagai bagian dari budaya menjadi landasan dari sebuah arsitektur. Arsitek sebagai perancang, 
menindaklanjuti perilaku sebagai bagian dari budaya pada suatu kajian yang digiring menjadi desain untuk beraktivitas manusia didalamnya. Di atas, telah dijelaskan bagaimana arsitek harus mampu menggunakan persepsinya sebagai perancang untuk menerjemahkan perilaku manusia ke dalam desain, sehingga hasil rancangannya mampu membawa perilaku manusia ke suatu kebajikan dan kemanfaatan (mengarahkan kepada hal yang lebih baik). Dapat dikatakan, dengan menganalisa behavior setting, arsitek akan dapat terbantu untuk lebih mengerti akan pola perilaku yang pernah terjadi dan mengantisipasi kemungkinan perilaku di masa mendatang. Ia juga dapat mendeteksi kecenderungan berperilaku dalam cara-cara tertentu untuk kemudian mengakomodasikan kekayaan perilaku ke dalam desain sebuah bangunan atau kompleks bangunan (Laurens, 2001: 144). Dari kutipan ini, dapat dilihat bahwa perilaku manusia yang dapat diakomodasikan ke dalam sebuah desain arsitektur. Tentunya hal ini tidak dapat terelakkan lagi jika arsitektur merupakan produk dari budaya, berdasarkan perilaku atau aktivitas yang mempengaruhinya.

Dengan kata lain, arsitek harus memiliki pengertian yang baik, atas representasi yang benar-benar akan dibentuk oleh penggunanya (manusia). Dan arsitek, hendaknya mempelajari reaksi klien dalam menggunakan rancangan arsitektur, serta melakukan pendekatan-pendekatan yang masuk akal dari cara manusia berperilaku didalamnya. Selain persepsi tentang perilaku, arsitek memerlukan pula kepekaan estetis yang selalu harus diimbangi dengan kepekaan sosial dan pengembangan rasio.

Dalam teorinya, arsitek menempatkan karyanya sebagai fungsionalisme cultural, artinya penciptaan karya arsitektur dilahirkan dengan menempatkan manusia sebagai sentral dan form follow culture, bentuk yang dirancang arsitek berasal dari pola perilaku, dijiwai oleh kehidupan manusia dan disesuaikan dengan kondisi sosial budaya.

Kondisi tersebut dituliskan pula dalam sistem arsitektur dan tatanannya, bahwa arsitektur harus sesuai dengan konteks situs (tempat), lingkungan, iklim, matahari, angin, temperatur, hujan, geografi, karakteristik pengindraan dan kultur suatu tempat. Lebih lanjut, arsitektur mengakomodasi sebuah 
program berupa persyaratan, keinginan, aspirasi dari pengguna, faktor sosial budaya, ekonomi, hukum, presenden dan tradisi historis (Ching, 2000: 44). Jika arsitek menyesuaikan dengan konteks tersebut, maka fungsi, bentuk, ruang serta teknik akan menghasilkan arsitektur. Oleh karena itu dapat dijelaskan bahwa dalam arsitektur peran manusia yang nantinya sebagai pengguna dan konteks tempat di mana didirikan sangat berpengaruh pada produk arsitektur itu sendiri.

Kebudayaan merupakan satu masukan atau unsur yang penting dalam membangun sebuah karya arsitektur, karena dengan memasukkan budaya yang didalamnya terdapat unsur manusia, akan menjadikan hasil arsitektur tersebut mempunyai identitas dan makna yang kuat tergantung di mana dia didirikan. Hal ini yang kemudian diolah dalam proses kreatif perancangan yang nantinya akan menghasilkan karya arsitektur yang mencerminkan budaya dari suatu daerah dan bermakna tinggi sesuai dengan guna dan citranya.

Pernyataan di atas diperkuat lagi dengan pernyataan Lincourt, seorang arsitek berkebangsaan Perancis, bahwa arsitektur adalah suatu keseluruhan simbiosis yang terdiri dari lima elemen dasar, yaitu manusia: makhluk penghuni dunia satu-satunya yang memiliki akal budi dan berbudaya, berkegiatan: alat mempertahankan eksistensinya dalam sebuah kehidupan, suatu lindungan/naungan budaya: terwujudnya tempat bernaung bagi kegiatan yang dilakukannya, alam lingkungan: tempat bernaung diwujudkan sesuai di dalam alam lingkungan, dan waktu: diproyeksikan melalui waktu, disesuaikan dengan perkembangan zaman.

Dari uraian panjang di atas, dapat diketahui tugas dan tanggung jawab seorang arsitek, bagaimana ia harus berkiprah memberikan segala hasil pikirnya ke dalam sebuah desain sehingga memberikan produk yang terbaik. Arsitek harus memberikan kontribusi desainnya dengan nilainilai kemanusiaan, menghubungkan perbandingan nilai-nilai manusia dengan kebutuhannya, memberi nilai pada ruang yang diciptakannya dengan memanfaatkan dan mengoptimalkan lima alat indra yang ada, sebagai perlengkapan desain untuk menghasilkan ide yang lebih banyak, kemudian mengimajinasikannya dalam pikiran. Harapannya, melalui 
analisa yang dilakukan, arsitek mampu menemukan dan menyelesaikan masalah secara kreatif.

Selain itu, arsitektur tidak lepas dari perilaku dan aktivitas manusia sebagai bagian dari budaya yang memberikan kontribusi yang kuat dalam proses perancangannya. Selain itu, arsitektur tidak dapat lepas dari konteks di mana dia didirikan, sehingga dengan unsur ini diharapkan arsitektur tidak hanya sebuah bangunan fisik yang hanya menonjolkan kegagahannya semata, melainkan sebuah karya arsitektur merupakan bangunan fisik yang didukung oleh makna dan beridentitas, sehingga akan menjadi wujud budaya yang luhur.

\section{Kesahajaan Arsitektur Kampung Naga}

Kampung Naga merupakan kawasan pemukiman penduduk pedalaman di wilayah Jawa Barat. Mereka mempunyai kebiasaan hidup yang teratur dan rapi, yang menyatu dengan alam dan lingkungan sekitar mereka. Lokasi Kampung Naga tersebut cukup mudah untuk dicapai dari jalan raya Garut Tasikmalaya. Lokasi pemukiman tersebut berada pada suatu lahan di kaki bukit, yang berada di tepi Sungai Ciwulan, dan di sekelilingnya terdapat bukit-bukit. Di sana terdapat sungai, mata air, hutan, lahan subur, serta aliran udara yang baik dan bersih yang menyediakan semua yang dibutuhkan untuk menjaga keberlangsungan pemukiman tersebut. Mereka sebagai penduduk yang tergolong awam dan terbelakang mempunyai prinsip dan nilai-nilai sederhana yang dapat diartikan sebagai satu kebersahajaan, sehingga dalam kehidupan mereka tidak timbul keinginan berlebih dalam memenuhi kebutuhan hidup, yang nantinya diharapkan akan melindungi penduduk Kampung Naga dari pengaruh luar yang negatif yang dapat menggeser nilai-nilai kehidupan mereka. Konsep warisan leluhur ini terwujud sampai pada kehidupan bermukim melalui aturan-aturan tertentu, sehingga secara fisik terbentuklah Kampung dengan rumah-rumah seragam yang sarat dengan makna dibaliknya (Padma, 2001: 7).

Nilai-nilai kehidupan keseharian penduduk Kampung Naga yang terdapat pada aturan-aturan tertentu ini merupakan suatu sistem kebudayaan mereka 
yang diterapkan secara turun-temurun. Aturan-aturan inilah yang merupakan suatu sistem kebudayaan yang berlaku dan diterapkan pada masyarakatnya dalam kehidupan sehari-hari. Hal ini yang kemudian berpengaruh dan mempengaruhi sikap, perilaku dan tindakan sehari-hari masyarakatnya dalam suatu sistem sosial masyarakat. Dan dari sistem kebudayaan dan sosial inilah muncul lingkungan fisik yang bersifat artefaktual sebagai aplikasi dari kedua sistem tersebut. Sehingga lingkungan fisik Kampung Naga inilah yang menjadi ciri khasnya dalam ranah arsitektur.

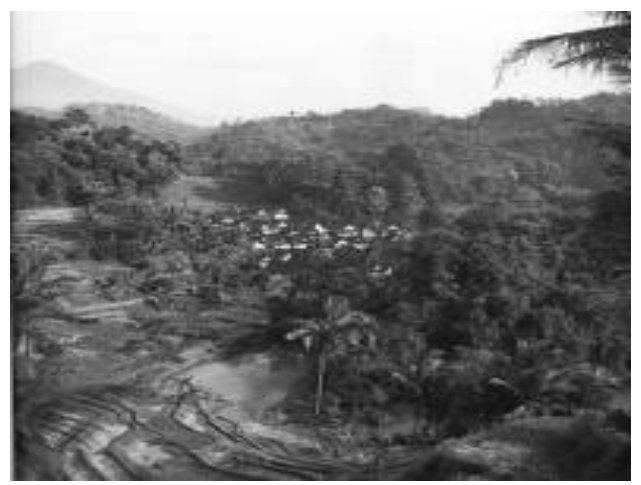

Gambar 1. Letak Kampung Naga yang berada di kaki perbukitan, sehingga menyatu dengan alam (Sumber: Padma, 2001: 7).

Prinsip penduduk Kampung Naga ini akan selalu mengusung kehidupan yang sederhana seperti apa yang telah dilakukan oleh mereka sehari-hari. Dengan sifat tersebut mereka tidak hidup berlebihan dan bersifat konsumtif seperti kebanyakan masyarakat saat ini. Sifat ini pulalah yang menjadikan Kampung Naga menjadi Kampung mandiri dan tidak bergantung pada dunia luar, karena mereka memanfaatkan secara optimal dan tidak berlebihan terhadap potensi alam dan lingkungan yang ada di daerah mereka. Hal ini berpengaruh dan mempengaruhi keberadaan tempat tinggal mereka yang secara fisik berada jauh dari keramaian kota.

Potensi lingkungan alam di sekitar mereka, mereka gunakan dengan seoptimal mungkin pada daur pengolahan lingkungan rumah tinggal mereka. Penduduk Kampung Naga, dengan segala kekurangan dan kelebihannya, 
mempunyai pengolahan sedemikian rupa sehingga mereka memiliki fasilitas yang cukup memadai bagi aktivitas dan kebutuhan warganya, seperti kebutuhan MCK, kebutuhan sosial, sampai pada kegiatan keagamaan yang di sini diwadahi oleh Masjid Kampung.

Adanya peraturan tentang zona kotor dan zona bersih yang memisahkan kegiatan yang berbau kotor seperti kandang hewan dan kegiatan manusia di kamar mandi dengan kegiatan bersih lainnya serta peraturan tentang daur atau siklus makanan yang diatur secara cermat berpengaruh pada tata letak dan kondisi permukiman mereka, sehingga senantiasa bersih dan teratur. Dari hal ini dapat dilihat bahwa sistem teknologi sebagai salah satu unsur kebudayaan dari suatu masyarakat sangat berpengaruh pada desain permukiman mereka secara arsitektural.

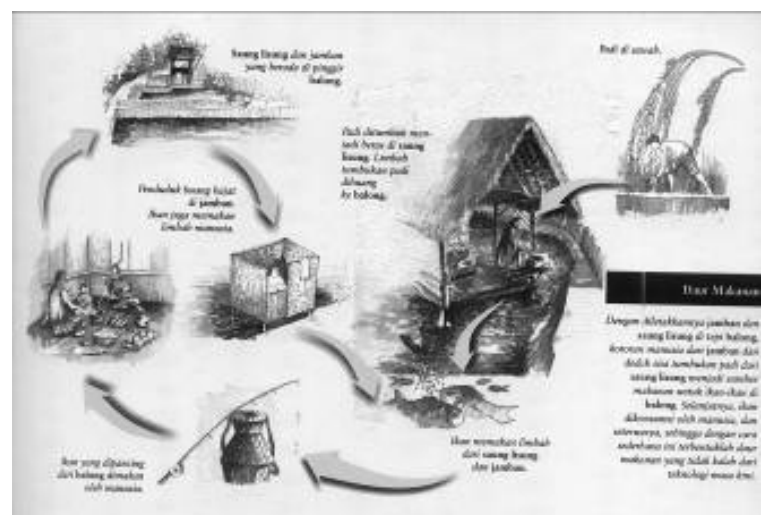

Gambar 2. Siklus makanan pada sistem utilitas Kampung Naga yang diatur dengan cermat sehingga tidak kalah dengan teknologi modern.

Kebutuhan dan hubungan sosial mereka diwadahi oleh beberapa fasilitas umum seperti masjid dan bale patemon. Aturan-aturan dasar yang menjadi konsep hidup masyarakat Kampung Naga inilah yang kemudian menjadi dasar untuk berperilaku yang berpengaruh terhadap kondisi pemukiman mereka yang mewadahi aktivitas mereka sehari-hari. 

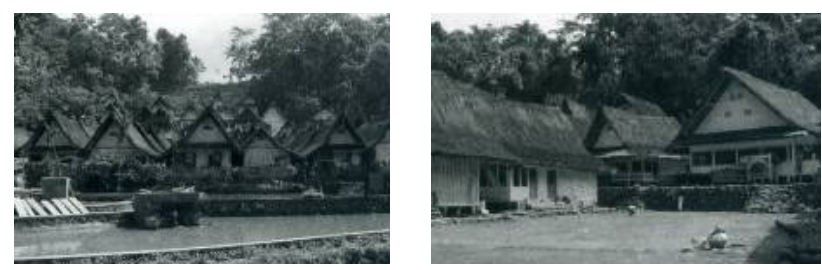

Gambar 3. Rumah-rumah di Kampung Naga yang teratur, bersih, dan rapi, sangat peduli lingkungan, sehingga keseimbangan lingkungan tetap terjaga (Sumber: Padma, 2001: 11).

Di sini juga terdapat pemisahan zona wanita dan pria yang diterapkan pada tata ruang di rumah tinggal mereka. Zona wanita terletak di sebelah kanan rumah yang terdiri dari pawon (dapur) dan goah. Sedangkan rumah sebelah kiri yaitu tepas dan golodog adalah daerah yang banyak digunakan oleh laki-laki. Selain itu terdapat pangkeng (ruang tidur) serta tengah imah (rumah) yang merupakan daerah netral (daerah pria dan wanita) (Padma, 2001: 21). Hal ini sangat sesuai dengan aturan dalam agama Islam yang mereka anut yang memisahkan area wanita dan pria. Kondisi fisik rumah mereka tersebut juga tidak lepas dari aturan-aturan sosial dan religi yang kuat yang mempengaruhi perilaku dan sikap hidup mereka yang berpengaruh pada karya arsitektur mereka yang khas, lihat gambar 4 .

Perilaku yang bersahaja juga dapat kita perhatikan pada dekorasi dan ornamen yang digunakan oleh penduduk Kampung Naga pada rumah tinggal mereka. Mereka memanfaatkan potensi yang ada di sekitar mereka seperti kayu, bambu dan rotan pada rumah mereka dengan tidak berlebihan. Dengan perilaku tersebut penduduk Kampung Naga tetap bertahan sampai dengan sekarang, dengan prinsip mereka yang tetap menjaga lingkungan walaupun mereka juga memanfaatkannya, maka keadaan lingkungan di daerah tersebut selalu seimbang, karena terdapat daur hidup yang jelas dan tidak ada salah satu dari mereka yang dirugikan. Di sini, dapat dilihat bahwa terjadi satu hubungan yang saling menguntungkan antara lingkungan dan manusia yang ada didalamnya. Berdasarkan atas salah satu teori perilaku, bahwa lingkungan yang dibangun, akan berpengaruh pada desain arsitektur, serta akan membentuk perilaku manusia didalamnya (architectural determinism). 
Lingkungan dapat membentuk kepribadian, lingkungan dan manusia saling mempengaruhi, lingkungan dapat mengubah perilaku manusia dan manusia dapat mengubah lingkungan, lihat gambar 5 .

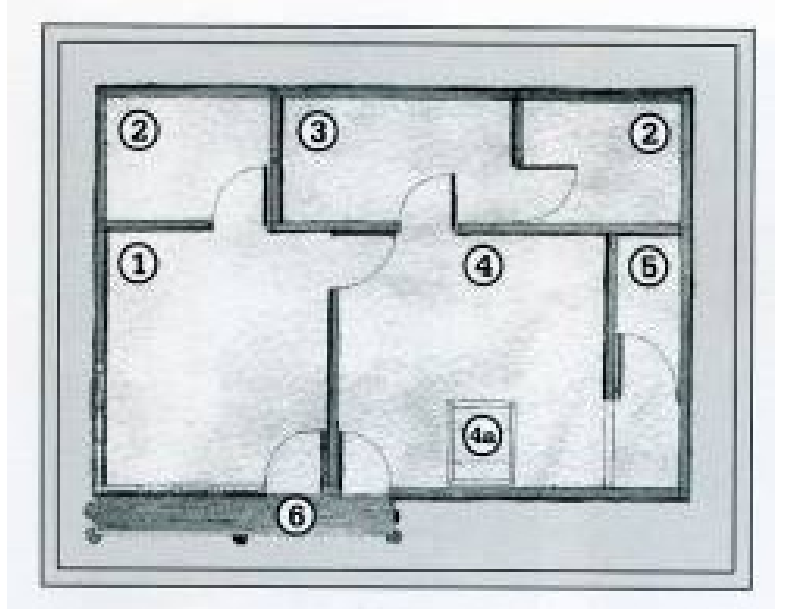

Keterangan:

1. Tepas

2. Pangkeng

3. Tengah imah

4. Pawon

4 Hawu

5. Goah

6. Golodog

Gambar 4. Denah rumah kampung Naga yang menerapkan pemisahan area wanita dan pria dalam rumah mereka (Sumber : Padma, 2001: 21).

Hal ini juga dapat kita temui pada pemakaian bahan-bahan alam yang merupakan potensi dari lingkungan alam mereka digunakan untuk melengkapi ornamen dalam rumah tinggal. Ragam hias yang mereka ciptakan sangatlah menarik apabila dikaitkan dengan kesahajaan mereka. Dari beberapa unsur dari pemukiman Kampung Naga tersebut dapat kita telaah bahwa setiap unsur arsitektural dari permukiman mereka merupakan hasil dari sikap hidup dan perilaku mereka sehari-hari tekait dengan aturan-aturan yang berlaku dalam masyarakat tersebut. Hal ini dapat meliputi setiap unsur dari kebudayaan yang ada seperti sistem sosial, teknologi, sistem religi dan sebagainya, yang dibahasakan dalam karya arsitektur yang bersahaja dari Kampung Naga. Arsitektur Kampung Naga juga dapat menegaskan bahwa keindahan dapat muncul dari kesahajaan dan kesederhanaan. Keindahan dapat muncul dari suatu hal yang parametrik atau terukur dengan yang non parametrik atau tidak terukur. Sesuatu yang terukur keindahannya mungkin dapat kita lihat secara fisik, namun yang tidak terukur merupakan 
keindahan yang hanya dapat dirasakan. Hal ini dapat menegaskan kembali bahwa arsitektur yang timbul dalam setiap kehidupan kita tidak lepas dari kebudayaan masyarakat yang ada disekitarnya. Arsitektur merupakan bagian dari suatu kebudayaan yang ada di masyarakat yang dapat dibentuk dari tiap-tiap unsurnya dan selalu terdiri dari sistem kebudayaan itu sendiri yaitu konsep, pemikiran dan aturan, adanya sikap perilaku dan tindakan yang mendukung, serta dari kedua unsur tadi muncullah arsitektur sebagai wujud fisik yang bersifat artefaktual.

\section{Simpulan}

Arsitektur merupakan bagian budaya yang ada di masyarakat yang dapat dibentuk dari tiap-tiap unsur dan selalu terdiri dari sistem kebudayaan itu sendiri yaitu konsep, pemikiran dan aturan, adanya sikap perilaku dan tindakan yang mendukung sebagai suatu sistem sosial, serta dari kedua sistem tadi munculah arsitektur sebagai wujud fisik yang bersifat artefaktual. Hal ini dapat kita lihat dari kesahajaan permukiman Kampung Naga yang

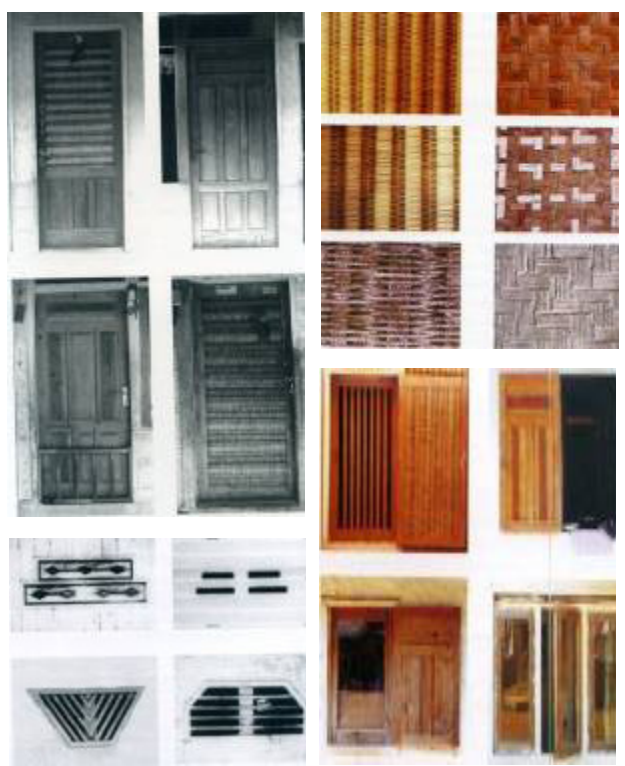

Gambar 5. Hasil alam yang dimanfaatkan untuk elemen rumah penduduk kampung Naga, dan menjadi pola ragam hias yang khas (Sumber: Padma, 2001: 28-29). 
memuat nilai-nilai budaya yang luhur dalam setiap elemennya.

Arsitektur yang muncul dari adanya pengaruh budaya dengan unsurunsur didalamnya dapat muncul pola-pola perilaku yang dibentuk oleh karya arsitektur tersebut, sehingga seyogyanyalah arsitektur dibangun dengan semangat dan dasar budaya yang luhur untuk menciptakan perilaku yang luhur pula.

\section{Daftar Pustaka}

Ching, Francis D.K. 2000. Arsitektur Bentuk, Ruang dan Tatanan. Jakarta: Erlangga.

Koentjaraningrat. 2005. Pengantar Ilmu Antropologi. Jakarta: Rineka Cipta.

Laurens, Joyce M. 2001. Studi Perilaku Lingkungan. Surabaya: Percetakan Universitas Kristen Petra.

Mangunwijaya, Y.B. 1995. Wastu Citra. Jakarta: Gramedia

Padma, Adry, dkk. 2001. Kampung Naga, Permukiman Warisan Karuhun. Bandung: Foris.

Ronald, Arya, 2007. Catatan Perkuliahan Antropologi Budaya. Yogyakarta. Pasca Sarjana Jurusan Teknik Arsitektur UGM.

Sunaryo, Ronny Gunawan, 2007. Mengikuti Langkah Pikir Romo Mangun. Dimensi Teknik Arsitektur. Volume. 35, Nomor 1: 4145. 